\title{
Single Stage Microinverter Based On Two- Switch DC-DC Flyback Converter
}

\author{
Edvardas Bielskis $^{1,2}$, Algirdas Baskys ${ }^{1,3}$, Martynas Sapurov ${ }^{1,3}$ \\ ${ }^{I}$ Center for Physical Sciences and Technology, \\ Sauletekio al. 3, LT-10257 Vilnius, Lithuania \\ ${ }^{2}$ Department of Electronics and Electrical Engineering, Siauliai University, \\ Vilniaus St. 141, LT-76353 Siauliai, Lithuania \\ ${ }^{3}$ Department of Computer Engineering, Vilnius Gediminas Technical University, \\ Naugarduko St. 41, LT-03227 Vilnius, Lithuania \\ edvardas.bielskis@su.lt
}

\begin{abstract}
The single stage photovoltaic microinverter based on couple of two-switch DC-DC flyback converters has been suggested. The results of simulation and experimental investigation for the case when photovoltaic microinverter operates in off-grid and grid-tied modes are presented. The proposed single stage microinverter is characterized by simple design and high efficiency.
\end{abstract}

Index Terms-Single stage microinverter; two-switch DCDC flyback converter; off-grid; grid-tied; efficiency.

\section{INTRODUCTION}

The photovoltaic inverters, which convert the DC voltage of photovoltaic module to standard AC voltage, include usually two conversion stages [1]: DC-DC boost converter, which steps up the voltage of photovoltaic module up to the level required for forming of standard $\mathrm{AC}$ voltage; inverter that converts the $\mathrm{DC}$ voltage to standard $\mathrm{AC}$ voltage and provides the synchronization with the mains power system.

The flyback converters are commonly used as DC-DC converters in low power photovoltaic inverters. The popularity of flyback DC-DC converters is caused by simple design, low production cost and high efficiency [2]-[5]. The drawback of such converter is fact that it generates high voltage spikes on switch transistor. The voltage spikes are caused by design specifics of flyback transformer [3]. To suppress the spikes the overvoltage clamp circuit has to be applied in classical flyback converter. Voltage spikes energy is dissipated in clamp circuit resistor in form of heat, lowering the efficiency and operating reliability of the converter [4]. The voltage spikes become especially high in boost DC-DC flyback converter that steps up the output voltage and, therefore, it operates at high primary circuit current [5], [6]. The application of simple overvoltage clamp circuit is not effective in such a case. Therefore, the active voltage suppression circuits, which are capable to accumulate the voltage spike energy in reactive components, have to be applied [5], [6]. However, the application of reactive components for voltage spike energy accumulation makes the converter more complex and less reliable. The

Manuscript received 13 November, 2016; accepted 21 May, 2017 effective utilization of spike voltage energy is important in DC-DC converters used for the realization of photovoltaic inverters, since the improvement of photovoltaic energy conversion efficiency is highly topical [7]. The DC-DC converter based on the two-switch topology suppress the spikes effectively and returns spikes energy to supply source, because of this, there is no need to use the reactive components for accumulation of spike energy [8].

The single stage photovoltaic microinverter based on couple of two-switch DC-DC flyback converters has been proposed in the paper. The microinverter is characterized by high efficiency and simple structure as compared to classical photovoltaic inverters.

\section{THE TWO-SWITCH DC-DC FLYBACK CONVERTER}

The circuit diagram of two-switch DC-DC flyback converter is presented in Fig. 1. The spike energy is returned back to the supply source $U_{1}$ using diodes D1 and D2. Therefore, the spikes are suppressed by voltage source $U_{1}$ and there is no need to use the reactive components for accumulation of spike energy.

The operation of converter can be divided into two cycles (Fig. 1). During the first cycle the switch transistors Q1 and Q2 are in state $\mathrm{ON}$ and the current flows through the transformer primary winding delivering the energy for transformer (Fig. 1(a)). The provided energy is accumulated in the form of transformer magnetic field. The primary winding voltage of the transformer can be expressed as follows

$$
U_{p r i}=L \frac{d\left[I_{1}(t)\right]}{d t}=U_{1}-I_{1}(t) \times \Sigma R_{1} \text {, }
$$

where $L$ is inductance of primary winding, $I_{1}(t)$ primary winding current, $\sum R_{1}$ the common active resistance of transistors Q1, Q2 and primary winding. The energy, which was accumulated in capacitor $\mathrm{C} 2$ during the second cycle delivers the current $I_{\mathrm{C} 2}=U_{2} / R_{2}$ to load R2.

The second cycle starts when the switch transistors Q1 and Q2 are closed and the energy accumulated in transformer is delivered to the secondary winding. The 
current of secondary winding is passed through the diode D3 to the load R2 (Fig. 1(b)). This energy is used for the charging of capacitor $\mathrm{C} 2$ as well. The capacitor charge current

$$
I_{C 2}(t)=I_{2}(t)-\frac{U_{2}}{R_{2}} .
$$

The energy accumulated in C2 is used for supply of load during the first cycle.

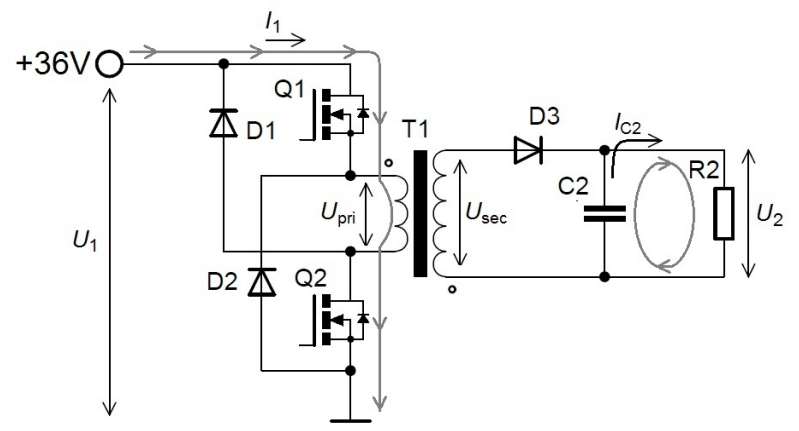

a)

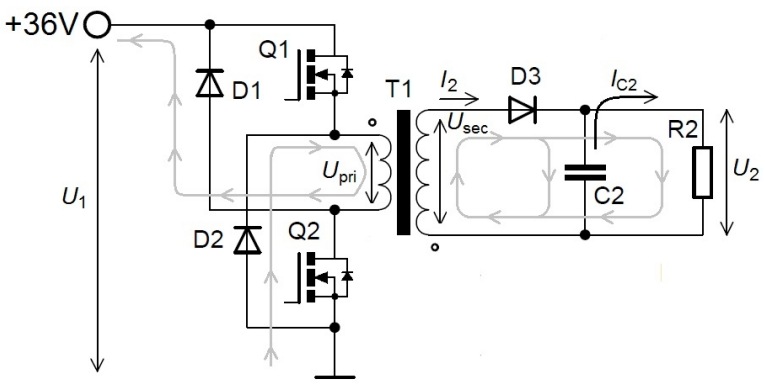

b)

Fig. 1. Circuit diagram of two-switch DC-DC flyback converter and current flow during the first (a) and second (b) operating cycles.

The reflected voltage $U_{\text {Rpri }}$ appears in the primary winding when the diode D3 conducts the current of the secondary winding

$$
U_{R p r i}=\frac{n_{\mathrm{pri}}}{n_{\mathrm{sec}}}\left(U_{2}+U_{D 3}\right)
$$

where $n_{\mathrm{pr}}$ and $n_{\mathrm{sec}}$ are number of primary and secondary windings turns, respectively, $U_{\mathrm{D} 3}$ is voltage drop across the diode D3.

The voltage spikes are generated in the transformer primary winding during the second cycle. They are delivered through the diodes D1 and D2 back to the voltage source $U_{1}$ and are suppressed.

The voltage spikes that affect the converter MOSFET transistor switch drain of classical DC-DC flyback converter can be twice higher as compared to converter input voltage $U_{1}$ even in the case when overvoltage clamp circuits are employed [4]. Therefore, the transistors with high operation voltage have to be used for realization of classical DC-DC flyback converter. The two-switch DC-DC converter topology allows us to eliminate the overvoltage, because of this the transistors with lower operating voltage can be employed. Transistors with lower operating voltage are characterized by lower voltage drop in state $\mathrm{ON}$, therefore, the power losses in converter switch can be decreased.

The two switch DC-DC flyback converter output operates as current source if the following inequality is valid

$$
U_{1}>\left(U_{2}+U_{D 3}\right) \frac{n_{\text {pri }}}{n_{\mathrm{sec}}}-\left(U_{D 1}+U_{D 2}\right),
$$

where $U_{\mathrm{D} 1}$ and $U_{\mathrm{D} 2}$ are voltage drops across the diodes D1 and $\mathrm{D} 2$, respectively.

If the inequality (4) is not valid converter operates as ordinary DC-DC converter, i.e. the voltage caused by the output voltage $U_{2}$ reflected to the primary winding is passed back to the converter supply.

\section{INVESTIGATION OF TWO-SWITCH DC-DC FLYBACK CONVERTER EFFICIENCY}

The two-switch DC-DC flyback converter (Fig. 1) was investigated experimentally. The model of converter was designed for investigation. The converter was supplied by $36 \mathrm{~V}$ DC voltage source and output of converter was loaded by resistive load. The types and parameters of main components of investigated converter model are presented in Table I.

TABLE I. TYPES AND PARAMETERS OF DC-DC FLYBACK CONVETER MODEL COMPONENTS.

\begin{tabular}{|c|c|}
\hline Component & Type, parameters \\
\hline Q1, Q2 & IRF3205 $(55 \mathrm{~V} ; 110 \mathrm{~A})$ \\
\hline D1, D2 & MBR1060 $(60 \mathrm{~V} ; 10 \mathrm{~A})$ \\
\hline D3 & MUR1560 $(600 \mathrm{~V} ; 15 \mathrm{~A})$ \\
\hline C1 & $0,22 \mu \mathrm{F} \times 400 \mathrm{~V}$ \\
\hline T1 & KA4823-CL \\
\hline
\end{tabular}

The investigation of converter was performed for the case when it works as boost DC-DC flyback converter. The converter efficiency dependences on output power $P_{2}$ at various values of load resistance and switching frequency have been obtained. The converter output power was changed by variation of pulse width of PWM voltage, i.e. by changing of output voltage $U_{2}$.

During the first experiment the converter efficiency dependences on output power at $39 \mathrm{kHz}$ switching frequency for the $990 \Omega, 660 \Omega$ and $330 \Omega$ converter load (R2) resistances were obtained. The dependences are given in Fig. 2. It is seen that they have the extreme point, at which the efficiency is maximal. The highest value of efficiency (0.93) of two-switch DC-DC flyback converter is reached at the highest load resistance $(990 \Omega)$. This can be explained by the fact that the same output power at higher load resistance is reached at lower load current. The power losses in diode D3 and in secondary winding of transformer become lower in such a case.

It is seen that the efficiency of converter is rather high in wide range of output power. It is not less than 0.90 in the range of output power 30 to $140 \mathrm{~W}$ at $990 \Omega$ load resistance. The efficiency decreases slightly at lower load resistance values.

Additionally, the efficiency dependence on output power of classical DC-DC converter was obtained for the $660 \Omega$ load and $39 \mathrm{kHz}$ switching frequency. It is seen (Fig. 2) that the efficiency of classical converter as compared to DC-DC 
flyback converter based on two-switch topology at the same load resistance is lower in the range of output power $40 \mathrm{~W}$ to $140 \mathrm{~W}$, for example, 0.87 and 0.91 , respectively, at $100 \mathrm{~W}$ output power.

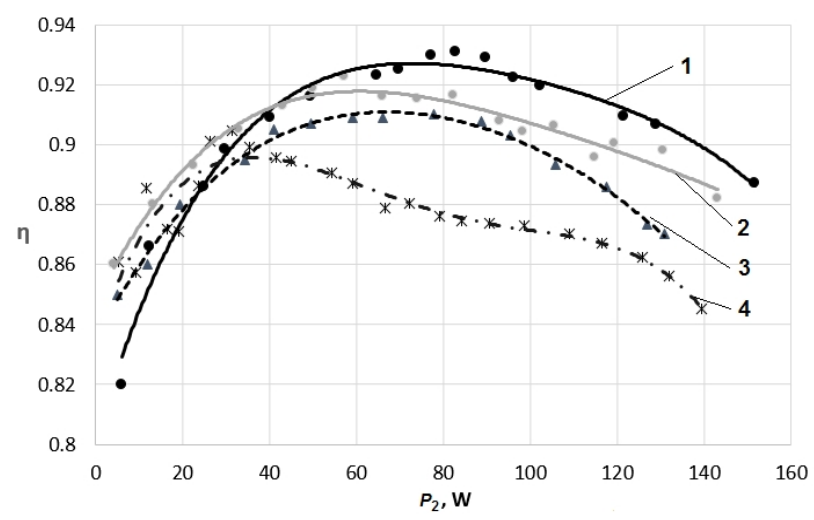

Fig. 2. The dependences of two-switch DC-DC flyback converter efficiency on output power at $39 \mathrm{kHz}$ switching frequency at various load resistances: $1 \Omega-990 \Omega ; 2 \Omega-660 \Omega ; 3 \Omega-330 \Omega$. Curve 4 presents the efficiency dependence of classical DC-DC flyback converter at $660 \Omega$ load resistance.

During the second experiment the converter efficiency dependences on output power at $600 \Omega$ converter load resistance for the $25 \mathrm{kHz}, 33 \mathrm{kHz}, 39 \mathrm{kHz}$ and $45 \mathrm{kHz}$ switching frequencies were obtained (Fig. 3). The highest efficiency $(0.93)$ is reached at $25 \mathrm{kHz}$ switching frequency. However, the significant drop of efficiency was observed at higher than $100 \mathrm{~W}$ output power because of transformer saturation at this frequency. The high enough efficiency (not less than 0.92 ) is reached in range of power $30 \mathrm{~W}$ to $110 \mathrm{~W}$ at $33 \mathrm{kHz}$ switching frequency. The switching power losses in switch transistors start to play more significant role at $39 \mathrm{kHz}$ and $45 \mathrm{kHz}$ switching frequency, therefore, the efficiency of two-switch DC-DC flyback converter is lower at these frequencies.

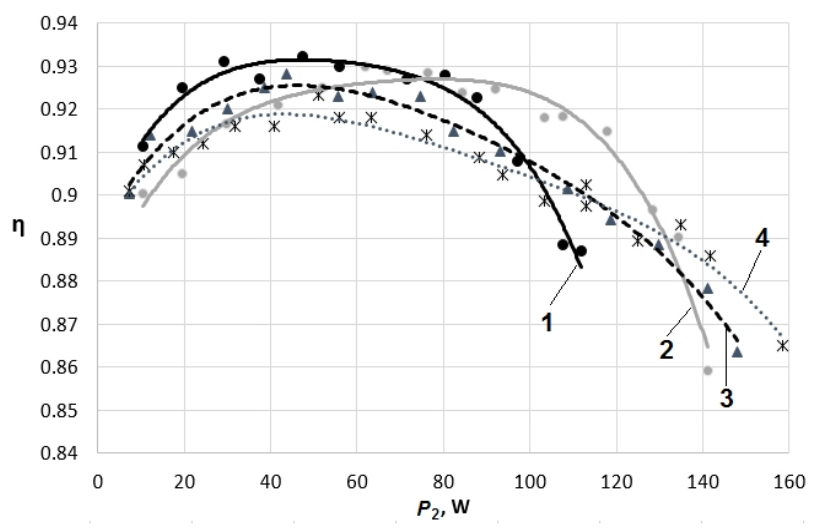

Fig. 3. The dependences of two-switch DC-DC flyback converter efficiency on output power at $600 \Omega$ converter load resistance for various switching frequencies: $1 \mathrm{kHz}-25 \mathrm{kHz} ; 2 \mathrm{kHz}-33 \mathrm{kHz} ; 3 \mathrm{kHz}-39 \mathrm{kHz}$; $4 \mathrm{kHz}-45 \mathrm{kHz}$.

\section{Single Stage Microinverter Based on Couple of TWO-SWITCH DC-DC FLYBACK CONVERTERS}

The proposed single stage photovoltaic microinverter is based on couple of two-switch DC-DC flyback converters. The circuit diagram of microinverter is presented in Fig. 4. Both two-switch DC-DC flyback converters are connected to primary winding of transformer. The couple of two quadrant switches, which are composed from transistors Q5, Q6 and diodes D1, D2, is used in the output of microinverter.

The positive half period of output voltage is generated using two-switch DC-DC flyback converter based on transistors Q2 and Q3 (transistors Q1 and Q4 are in state OFF) and the output voltage is delivered to load through the diode D1 and transistor Q5, which is in state ON. The negative half period of output voltage is formed similar as positive using two-switch DC-DC flyback converter based on transistors Q1 and Q4 (transistors Q2 and Q3 are in state OFF) and the output voltage is delivered to load through diode D2 and open transistor Q6.

The energy of voltage spikes, which is generated by flyback transformer during the switch transistor turn off is returned to microinverter supply through the internal diodes of switch transistors Q1-Q4.

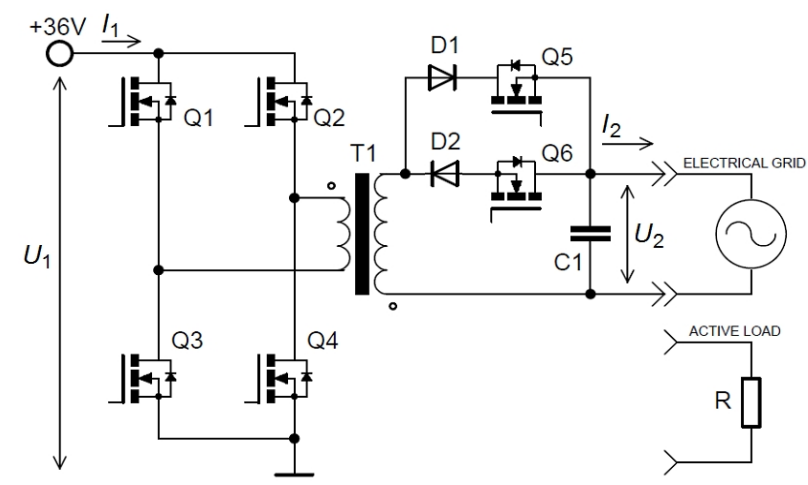

Fig. 4. The circuit diagram of single stage microinverter.

The single stage microinverter was investigated experimentally and using simulation. The simulation was performed using Matlab/Simulink software. The experimental model of microinverter was designed for experimental investigation. The types and parameters of main components of investigated single stage microinverter are presented in Table II. The investigation was performed for two kinds of microinverter load: resistive load (off-grid operation mode); electrical grid load (grid-tied operation mode). The dependences of microinverter efficiency on output power were obtained (Fig. 5). The investigation in off-grid operation mode was performed for the $860 \Omega$ load resistance. The experimentally obtained dependence (Fig. 5, curve 1) shows that efficiency reaches $0.947 \mathrm{~W}$ at $26 \mathrm{~W}$ output power. However, at power higher than $70 \mathrm{~W}$ it drops below $0.9 \mathrm{~W}$. The dependence obtained using simulation (Fig. 5, curve 3) shows higher efficiency, which reaches $0.955 \mathrm{~W}$ at $45 \mathrm{~W}$. The simulation error of efficiency in comparison to experimental results is $5 \%$ at $20 \mathrm{~W}$ and reaches $8 \%$ at $100 \mathrm{~W}$. The efficiency of microinverter decreases at higher power because the current of components increases significantly and, as consequence, the power losses in microinverter components rise.

In the case when microinverter operates in grid-tied mode, the experimentally obtained efficiency is higher than $0.9 \mathrm{~W}$ in range of output power $14 \mathrm{~W}$ to $72 \mathrm{~W}$ (Fig. 5, curve 2). The maximal efficiency value $0.925 \mathrm{~W}$ is reached at $40 \mathrm{~W}$ output power. The simulation shows (Fig. 5, curve 4) higher efficiency, which reaches $0.94 \mathrm{~W}$ at $35 \mathrm{~W}$. The simulation error of efficiency in respect to experimental results is $2 \%$ at 
$60 \mathrm{~W}$ and reaches $6 \%$ at $100 \mathrm{~W}$.

TABLE II. TYPES AND PARAMETERS OF MICRINVERTER COMPONENTS

\begin{tabular}{|c|c|}
\hline Component & Type, parameter \\
\hline Q1, Q2, Q3, Q4 & IRF3205 $(55 \mathrm{~V} ; 110 \mathrm{~A})$ \\
\hline Q5, Q6 & 2SK2717 $(900 \mathrm{~V} ; 5 \mathrm{~A})$ \\
\hline D1, D2 & FUF5408 $(1000 \mathrm{~V} ; 3 \mathrm{~A})$ \\
\hline $\mathrm{C} 1$ & $0,22 \mu \mathrm{F} \times 400 \mathrm{~V}$ \\
\hline $\mathrm{T} 1$ & KA4823-CL \\
\hline
\end{tabular}

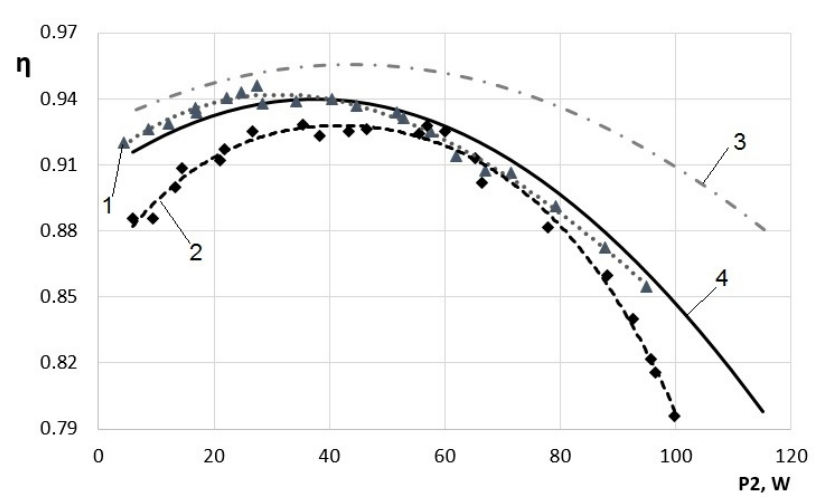

Fig. 5. The dependences of single stage microinverter efficiency on output power at $39 \mathrm{kHz}$ switching frequency: 1, 3- off-grid operation mode, load resistance $860 \Omega ; 2,4$ - grid-tied operation mode. Curves 1 and 2 are obtained experimentally, 3 and 4 - using simulation.

The waveforms of microinverter output voltage and current for the case when microinverter operates in grid-tied mode, i.e. it delivers the current to the grid, were analysed. The waveforms were obtained using simulation (Fig.6(a)) and experimental investigation (Fig. 6(b)).

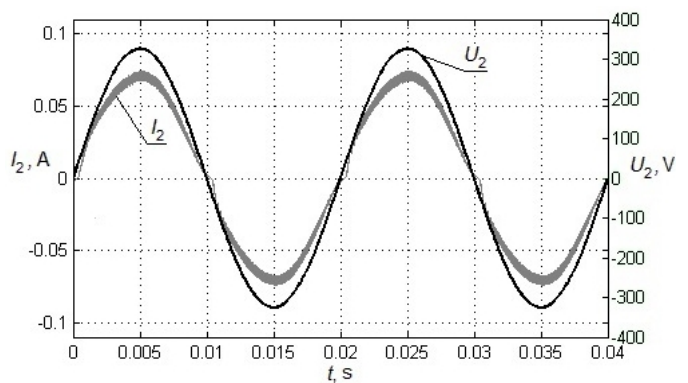

a)

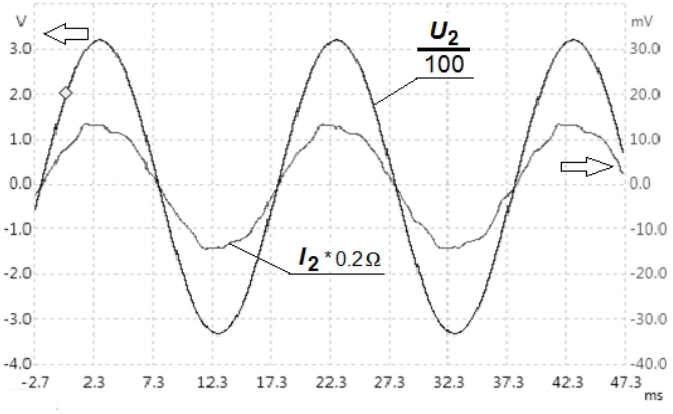

b)

Fig. 6. The waveforms of single stage microinverter output voltage and current for the situation when microinverter operates in grid-tied mode at $39 \mathrm{kHz}$ switching frequency: a - simulation results; b - experimental investigation results.

The simulation was performed using Matlab/Simulink software. It is seen that the experimentally obtained waveform of current is distorted $(\mathrm{THD}=11.2 \%)$. The distortions of experimentally obtained voltage waveform and simulated waveforms of voltage and current are negligible.

\section{CONCLUSIONS}

The efficiency of DC-DC flyback converter based on twoswitch topology is about $3 \%$ higher as compared to classical DC-DC flyback converter.

The proposed single stage microinverter is based on couple of two-switch DC-DC flyback converters and is characterized by high efficiency and simple design.

The maximal microinverter efficiency 0.947 in off-grid operation mode was reached at $26 \mathrm{~W}$ output power and $860 \Omega$ load. In case when microinverter operates in grid-tied mode the maximal efficiency value 0.925 is reached at $40 \mathrm{~W}$ output power.

The simulation error of microinverter efficiency dependence on output power is $(2-8) \%$ as compared to experimental results.

The THD of experimentally obtained current curves is $11.2 \%$, for the cases when microinverter operates in gridtied mode.

The distortions of experimentally obtained voltage waveform and simulated waveforms of voltage and current are negligible.

\section{REFERENCES}

[1] A. S. K. Chowdhury, K. M. A. Salam, M. A. Razzak, "Single-phase grid-tie photovoltaic inverter using maximum power point tracking with flyback converter", in Conf. Developments in Renewable Energy Technology (ICDRET), 2014, pp. 95-91. [Online]. Available: http://dx.doi.org/ 10.1109/ICDRET.2014.6861670

[2] M. A. K. A. Biabani, "Simulation, mathematical calculation and comparison of power factor and efficiency for forward, fly back and proposed forward-flyback converter", in Conf. Published in: Electrical, Electronics, and Optimization Techniques (ICEEOT), pp. 1583-1589, 2016. [Online]. Available: http://dx.doi.org/ 10.1109/ICEEOT.2016.7754952

[3] H. Kim, M. Kim, "Duty-ratio feedforward controller design for single-stage flyback CCM inverter", Electronics Letters, vol. 52, pp. 2053-2055, 2016. [Online]. Available: http://dx.doi.org/10.1049 /el.2016.3658

[4] M. Kim, S. Choi, "A fully soft-switched single switch isolated DCDC converter", IEEE Trans. on Power Electronics, vol. 30, pp. 4883-4890, 2015. [Online]. Available: http://dx.doi.org/10.1109/ TPEL.2014.2363830

[5] K. Soltanzadeh, H. Khalilian, M. Dehghani, "Analysis, design and implementation of a zero voltage switching two-switch CCM flyback converter", IET Circuits, Devices \& Systems, vol. 10, pp. 20-28, 2016. [Online]. Available: http://dx.doi.org/10.1049/iet-cds.2014. 0329

[6] S. Larousse, H. Razik, R. Cellier, "Self-calibrated valley switching for wide range Flyback active-clamp DC-DC converter", in IEEE 8th Int. Conf. Power Electronics and Motion Control, 2016, pp. 1134-1138. [Online]. Available: http://dx.doi.org/ 10.1109/IPEMC.2016.7512447

[7] K. Juang, S. J. Chiang, W. M. Xiao, "A grid-tied flyback-based PV inverter with BCM variable frequency voltage mode control", in Conf. Int. Symposium on Intelligent Signal Processing and Communications Systems, 2012, pp. 598-603. [Online]. Available: http://dx.doi.org/ 10.1109/ISPACS.2012.6473560

[8] M. A. Pagliosa, T. B. Lazzarin, I Barbi, "Output characteristics of two-switch Flyback including the leakage inductance", in IEEE Conf. Power Electronics and 1st Southern Power Electronics (COBEP/SPEC), 2015, pp. 162-167. [Online]. Available: http://dx.doi.org/10.1109/COBEP.2015.7420077. 